Available online on 15.05.2018 at http://jddtonline.info
Journal Of Drug Delivery and Therapeutics
Open Access to Pharmaceutical and Medical Research
$\begin{gathered}\text { @ 2011-18, publisher and licensee JDDT, This is an Open Access article which permits unrestricted non- } \\ \text { commercial use, provided the original work is properly cited }\end{gathered}$

Open Access

Research Article

\title{
STUDIES ON ANTIMICROBIAL POTENTIAL OF BAUHINIA VAHLII STEM EXTRACTS
}

\author{
Divaker Shukla*, Kavita Gahlot \\ Pharmacognosy and Phytochemistry Laboratory, Faculty of Pharmacy, IFTM University, Moradabad-244001-India
}

\begin{abstract}
The antimicrobial potential of ethanolic extract (EE) and aqueous extract (AE) of stem of Bauhinia vahlii were evaluated in vitro against some specific bacterial and fungal species employing well diffusion method and serial dilution methods. The patterns of inhibition varied with the stem of Bauhinia vahlii extracts, the solvent used for extraction and the organisms tested. The strains used included Staphylcoccus aureus, Bacillus subtilis, Escherichia coli, Pseudomonas aeruginosa, Salmonella typhi, (reference strain) and two fungal strains including (Candida albican and Aspergillus niger) were used for antimicrobial activity assessment. The EE of stem showed a relatively potent antimicrobial activity than the AE. Further studies are to be carried out to find out the chemical composition of the plant extracts.
\end{abstract}

Keywords: Bauhinia vahlii, Staphylcoccus aureus, Bacillus subtilis, Escherichia coli Pseudomonas aeruginosa, Salmonella typhi.

Article Info: Received 10 Feb, 2018; Review Completed 02 May 2018; Accepted 10 May 2018; Available online 15 May 2018

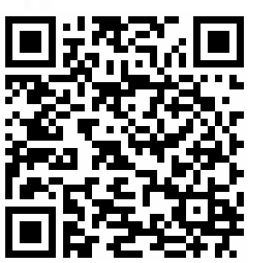

Cite this article as:

Shukla D, Gahlot K, Studies on antimicrobial potential of Bauhinia vahlii stem extracts, Journal of Drug Delivery and Therapeutics. 2018; 8(3):106-108 DOI: http://dx.doi.org/10.22270/jddt.v8i3.1714

*Address for Correspondence:

Divaker Shukla, Pharmacognosy and Phytochemistry Laboratory, Faculty of Pharmacy, IFTM University, Moradabad-244001, India

\section{INTRODUCTION}

Literature data on plant based medicine as recommended by WHO indicates that present era is based on herbal remedies ${ }^{1}$.In order to treat various ailments associated with common health problem, plant based medicines are gaining popularity now a days. Among various common health problems, infections (acute or chronic) are considered as one of the most important health problem which needs major attention ${ }^{2}$. The medicinal importance of plants depends on chemical compositions which produce a definite physiological response on the body system. The most important of these bioactive compounds of plants are alkaloids, flavonoids, tannins and phenolic compounds. Developing countries like India depend on plant resources mainly for herbal medicines, food, forage, construction of dwellings, making household implements, sleeping mats, and for fire and shade ${ }^{3}$. The application of plant based medicines is well known in tribal areas of many developing countries. Traditional literature claims that their medicine is cheaper, more effective and produces negligible side effects in comparison to synthetic medicines. In such countries people use folk medicine in order to treat common infections related problem. Bauhinia vahlii species used in folk medicine were selected to determine their antimicrobial activity. In general such plants are employed in folk system of medicine to treat skin diseases, venereal diseases, respiratory problems and nervous disorders. Literature review suggested there is lack of scientific literature on selected plants especially on antimicrobial studies. The development of drug resistance in human pathogens against commonly used antibiotics has necessitated a search for new antimicrobial substances from other sources including plants based medicine. Search of Bauhinia vahlii for antimicrobial activity is important to investigate the potential new compounds for medicinal application ${ }^{\mathbf{4 , 5 , 6}}$. The present work covers the antimicrobial evaluation of aqueous and ethanolic extracts of Bauhinia vahlii stem. 


\section{Plant profile of Bauhinia vahlii. ${ }^{7}$}

Botanical name: Bauhinia vahlii

Family : Caesalpiniaceae

Local Name : Maljan

Part of plant used: Stem

\section{METHODS}

\section{Plant materials and preparation of extracts}

The stems of Bauhinia vahlii were collected from Haridwar District, Uttarakhand, India. The plant authentication was done by Dr. S. K. Sinha, Scientist-E, Botanical survey of India (BSI), The air-dried plant materials were grounded into fine powder and subjected to extraction using hot water and ethanol $(80 \%)$. The extracts were termed as ethanolic extract (EE) and aqueous extract (AE). After filtration of both the extracts, the extracts were evaporated to dryness in rota evaporator.

\section{Bacterial cultures}

The bacterial strains including Staphylcoccus aureus, Bacillus subtilis, Escherichia coli, Pseudomonas aeruginosa, Salmonella typhi, (reference strain) and two fungal strains including (Candida albican and Aspergillus niger) were used for antimicrobial activity assessment.

\section{Bacterial susceptibility evaluation}

The antimicrobial activity was evaluated by the well diffusion method as per guidelines of National Committee for Clinical Laboratory Standards (NCCLS) 8. The petridish containing $20 \mathrm{ml}$ Agar medium was seeded with a standardized inoculums $1-2 \times 107 \mathrm{cfu} / \mathrm{ml}$. Wells (6 mm diameter) on Agar plates were made into agar and $50 \mu \mathrm{l}$ of plant extracts were evaluated in a concentration of $100 \mathrm{mg} / \mathrm{ml}$. The incubation was performed at $37^{\circ} \mathrm{C}$ for $24 \mathrm{~h}$. The same procedure was performed for the determination of antifungal activity and incubated at $25^{\circ} \mathrm{C}$ for $24 \mathrm{~h}$. The assessment of antimicrobial activity was dependent upon measurement of the diameter of the inhibition of zone formed around the well. A standardized $30 \mu \mathrm{g}$ Ampicillin and Ciprofloxacin were used as control group drug ${ }^{9}$.

\section{Assessment of Minimum Inhibitory Concentration (MIC) and Minimum Bactericidal Concentration (MBC)}

The MIC value was determined using micro dilution method, employing serial dilution of ( 2 folds) and plant extracts according to the MIC of the extracts were determined by dilution of Bauhinia vahlii (stem) employing various concentrations of 0.0-45, 0.0-55, 0.0$42,0.0-55,0.0-36,0.0-42,0.0-45 \mathrm{mcg} / \mathrm{ml}$ respectively. Equal volume of each extract and nutrient broth were mixed in separate test tube. $0.1 \mathrm{ml}$ of standardized inoculums $(1-2 \times 107 \mathrm{cfu} / \mathrm{ml})$ was added in each tube prepared as above. The tubes were incubated aerobically at $37^{\circ} \mathrm{C}$ for $18-24 \mathrm{~h}$. Two control tubes were maintained as per protocol for each test batch. These included antibiotic control (tube containing extract and growth media without inoculums) and organism control (tube containing the growth medium, saline and the inoculums).The lowest concentration (highest dilution) of the extract that produced no visible bacterial growth (no turbidity) when comparison was made with the control tubes were regarded as MIC. However, the MBC was observed by further sub dilution of test solution on to a fresh drug free solid medium and incubated further for 18-24 $\mathrm{h}$. The highest dilution that resulted no signal bacterial colony on the solid medium was taken as MBC.

\section{RESULTS AND DISCUSSION}

The finding of antimicrobial activity reflected good antimicrobial activity against different bacterial strain but relatively less activity against fungal strain. Both $\mathrm{EE}$ and $\mathrm{AE}$ of this plant were effective on all the test bacterial strains. On the other hand, the extracts (EE and $\mathrm{AE}$ ) of stem of Bauhinia vahlii were found less potent against the fungus as observed by zones of inhibitions (ZOI), the finding are presented (Table 1).

The MIC and MBC values obtained for extracts against the bacterial strains varied from plant extract to the other. For instance, MIC values of 30.6, 31.3, 28.6, 30.2 and $29.2 \mathrm{mcg} / \mathrm{ml}$ were obtained for AE of Bauhinia vahlii while the corresponding MBC values are 31.4, $34.8,40.2,36.3$ and $30.8 \mathrm{mcg} / \mathrm{ml}$ against $S$. aureus, $B$. subtilis, E. coli, $P$. aeruginosa and S. typhi respectively (Table 2).

The MIC and MBC values of 25.6; 30.2 and 21.5; 34.2 and 24.6; 36.3 and $22.8 ; 32.6$ and 24.2; 30.4 were recorded for EE of Bauhinia vahlii against $S$. aureus, $B$. subtilis, E. coli, P. aeruginosa and S. typhi respectively (Table 3).

The plant extracts were found to be bacteriostatic at lower concentrations and bactericidal at higher concentrations as observed by MIC and MBC values shown in Tables 2 and Table 3. The plants constitute an effective source for traditional and modern medicines. Herbal medicines have been shown to have genuine utility and about $80 \%$ of tribal person depends on its primary health care ${ }^{10}$. Since years, the WHO advocated that countries should interact with traditional medicines with a view to identify and exploit aspects the safe and effective remedies for ailments of both microbial and non-microbial origin ${ }^{11}$. The findings of present study indicated that Bauhinia vahlii, which is commonly used by traditional medical practitioners to cure bacterial health problems. The crude extracts of Bauhinia vahlii were weakly active against fungal strains with $\mathrm{EE}$ stronger antibacterial activity than water extracts. The investigations further showed that both $\mathrm{EE}$ and $\mathrm{AE}$ of Bauhinia vahlii were active against bacterial species. The MIC values of Bauhinia vahlii (EE and $\mathrm{AE}$ ) plant extracts were lower than $\mathrm{MBC}$ values related that both the plant extract were bacteriostatic at lower concentration and bactericidal at higher concentrations. The EE of plant exerted greater antibacterial activity than corresponding $\mathrm{AE}$ in same concentration (Table 1). These observations may be associated with two reasons; $1^{\text {st }}$ the nature of biologically active components (Alkaloids, Anthraquinone, saponins and tannins) which 
could be enhanced in presence of ethanol. It has been documented that these components are well known for anti-microbial activity. Secondly, the stronger extraction efficiency of ethanol could have caused greater active constituents responsible for anti-microbial activity. Traditionally, these plants are soaked in ethanol or water, for days, large quantities of these extract, which lack specific concentration are usually administrated to patients ${ }^{\mathbf{1 2}}$. The findings support the traditional claim that these medicinal plants are preferably extracted in ethanol.

Table 1: Anti-microbial activity of stem of the Bauhinia vahlii extracts (EE and AE) on different bacterial and fungal strains.

\begin{tabular}{|l|l|l|l|l|l|l|l|l|l|l|l|l|l|l|}
\hline \multirow{3}{*}{ Plant name } & \multicolumn{10}{|c|}{ Zone of inhibition (ZOI) (mm) } \\
\cline { 2 - 15 } & \multicolumn{10}{|c|}{ Ethanolic extract } & \multicolumn{1}{|c|}{ Aqueous extract } \\
\hline \multirow{3}{*}{ Bauhinia vahlii } & 1 & 2 & 3 & 4 & 5 & 6 & 7 & 1 & 2 & 3 & 4 & 5 & 6 & 7 \\
\cline { 2 - 14 } & 42 & 26 & 54 & 42 & 32 & 56 & 60 & 30 & 22 & 44 & 36 & 24 & 54 & 58 \\
\hline
\end{tabular}

Activity key: Table indicates average zone of inhibition (in $\mathrm{mm}$ ), Ampicilline and Ciprofloxacin $=$ commercial antibiotics, $1=S$. aureus, $2=B$. subtilus, $3=$ E.coli, $4=P$. aeruginosa, $5=S$. typhi, $6=$ Candida albican, and $7=A$. niger .

Table 2: MIC and MBC of $\mathbf{A E}$ on different bacterial species (in $\mathrm{mcg} / \mathrm{ml}$ )

\begin{tabular}{|l|l|l|l|l|l|l|l|l|l|l|}
\hline \multirow{2}{*}{$\begin{array}{l}\text { Plant } \\
\text { Name }\end{array}$} & \multicolumn{2}{|c|}{ 1 } & \multicolumn{2}{c|}{ 2 } & \multicolumn{2}{c|}{ 4 } & \multicolumn{2}{c|}{ 5 } \\
\cline { 2 - 11 } & MIC & MBC & MIC & MBC & MIC & MBC & MIC & MBC & MIC & MBC \\
\hline B.vahlii & 30.6 & 31.4 & 31.3 & 34.8 & 28.6 & 40.2 & 30.2 & 36.3 & 29.2 & 30.8 \\
\hline
\end{tabular}

Activity key: $\mathrm{mcg}=$ microgram, $1=S$. aureus, $2=$ B. subtilus, $3=$ E.coli, $4=P$. aeruginosa, $5=S$. typhi.

Table 3: MIC and MBC of EE on different bacterial species (in $\mathrm{mcg} / \mathrm{ml}$ )

\begin{tabular}{|l|l|l|l|l|l|l|l|l|l|l|}
\hline \multirow{2}{*}{$\begin{array}{l}\text { Plant } \\
\text { Name }\end{array}$} & \multicolumn{2}{|c|}{1} & \multicolumn{2}{c|}{ 2 } & \multicolumn{2}{c|}{ 4 } & \multicolumn{2}{c|}{ 5 } \\
\cline { 2 - 11 } & MIC & MBC & MIC & MBC & MIC & MBC & MIC & MBC & MIC & MBC \\
\hline B.vahlii & 25.6 & 30.2 & 21.5 & 34.2 & 24.6 & 36.3 & 22.8 & 32.6 & 24.2 & 30.4 \\
\hline
\end{tabular}

\section{CONCLUSION}

The present results therefore prove the scientific background of traditional use of both $\mathrm{EE}$ and $\mathrm{AE}$ of Bauhinia vahlii. But in vivo studies on these medicinal plants are necessary and require determine toxicity of active constituents, their side effects, serum- attainable levels, pharmacokinetic attributes and diffusion in different body sites. The anti-microbial activities could be enhanced if active components are purified and adequate dosage is decided for proper administration. This represents the preliminary report on the anti-microbial activity of stem of Bauhinia vahlii medicinal plants in India.

\section{REFERENCES}

1. World Health Organization (WHO). National Policy on Traditional Medicine and Regulation of Herbal Medicines. Geneva: 2005

2. Anonymous 'The Wealth of India - Raw Material', It Edn., CSIR, New Delhi, 2003; 1:54-55.

3. Chauhan R, Saklani S, Bauhinia vahlii: Plant to be Explored, International Research Journal of Pharmacy, 2013; 4(8):5-9.

4. Panda P, Singh S, Pal A, Dash Priyanka, and Ghosh Goutam, Antimicrobial and Immunomodulatory Activities of Methanolic Extract of Bauhinia vahlii, Research Journal of
Pharmaceutical, Biological and Chemical Sciences (RJPBCS), 2015; 6(3):655-660.

5. Bagchi B, Banerjee D, Diversity of Fungal Endophytes in Bauhinia vahlii From Different Regions of Paschim Medinipur District Of West Bengal, International Journal of Science, 2013; 2:748-756.

6. Jaime A. and Da Silva Teixeira, A Review of the In Vitro Propagation of Bauhinia species, Journal of Horticultural Research, 2013; 21(1):39-47.

7. Kirtikar KR, Basu BD, Indian Medicinal Plants, International Book Distributors, Dehradun, 1999; 2:895-899.

8. National Committee for Clinical Laboratory Standards NCCLS Methods for Dilution antimicrobial susceptibility tests for bacteria that grow aerobically: approved standards- fifth edition. NCCLS document M7-A5. NCCLS: Wayne, PA, USA, 2000.

9. Alam M.T, Karim MM, Shakila N, Antibacterial Activity of Different Organic Extracts of Achyranthes Aspera and Cassia Alata , J. Sci. Res 2009; 1(2):393-398.

10. Farnsworth NR, Akerele O, Bingel AS, Medicinal plants in therapy. Bulletin of World Health Organization 1985; 63:965981.

11. World health organization (WHO). The promotion and development of traditional medicine, Technical report series, $1978,622$.

12. Ajaiyeoba E. Phytochemical and antibacterial properties of Parkia biglobosa and P. bicolor leaf extracts. Afr. J. Biomed. Res. 2002; 5:125-129. 